\title{
PERCOBAAN PENGOLAHAN AIR LIMBAH YANG MENGANDUNG \\ BAHAN AKTIF MIPC DENGAN PROSES PENGGUMPALAN DAN \\ PENGENDAPAN
}

Oleh :

Ir. Siti Noer Tri Hidayati *)

Abstract

Experiment has been carried out to waste water containing MIPC which is treated by floculation and sedimentation process. It seen thet treatment time, type of treated material and the concentration of floculant influence the treatment result. In this case the floculant and sedimentation treatment method gave a better result.

\section{PENDAHULUAN}

Pengolahan air limbah yang dihasilkan oleh industri pestisida merupakan suatu masalah yang penting bagi suatu industri pestisida. Air yang dipergunakan untuk mencuci, membersihkan peralatan penampungan dan peralatan lain akan mengandung pestisida. Air pencucian ini tidak dapat langsung dialirkan ke dalam saluran pembuangan umum, tetapi harus dilakukan pengolahan lebih dahulu.

Teknologi pengolah yang dipergunakan oleh industri kimia dasar terlalu mahal untuk diterapkan pada industri pestisida yang kecil dan menengah. Oleh sebab itu perlu dikembangkan kemungkinan lain untuk membantu industri pestisida dalam mengendalikan air limbahny a yang mengandung pestisida.

Dalam penelitian ini dilakukan percobaan pengolahan air limbah yang mengandung bahan aktif MIPC secara sederhana yaitu dengan melakukan proses penggumpalan dan pengendapan.

\section{PENGOLAHAN AIR LIMBAH YANG MENGANDUNG PESTISIDA}

Sistem perairan mulai tercemar oleh pestisida karena pemakaian yang berlebihan atau secara tidak disengaja, hal yang terakhir merupakan hal yang sering terjadi. Pencemaran yang tidak disengaja terjadi karena penyemprotan, di dalam proses pengendapan, pengairan dan pelepasan apabila sejumlah besar air limbah industri memasuki badan air atau bila sisa pestisida atau wadah pestisida dibuang ke dalam air.

Indikasi bahwa suatu sistim perairan telah tercemar oleh pestisida dapat diketahui dari adanya fluktuasi residu pestisida di dalam air atau dasar endapan.

Pengolahan air buangan industri ada bermacam-macam mulai dari yang paling sederhana sampai pengolahan dengan sistim detoksikasi yang canggih.

Detoksikasi adalah perubahan dari bahan yang bersifat beracun menjadi bahan yang kurang/tidak beracun.

Proses detoksifikasi dapat dilakukan oleh biota \& abiota.

A. Detoksikasi oleh biota

Pestisida yang dipergunakan diareal pertanian, perkebunan atau di perumahan untuk membasmi nyamuk dan serangga-serangga lainnya, pengaruhnya akan tersebar ke media-media lain, terutama pada air, tanah \& organisma yang terdapat di alam. Di alam pestisida diserap oleh berbagai kom-

*) Staf Balai Penelitian Pupuk dan Petrokimia. (BBIK). 
ponen lingkungan, kemudian terangkut ke tempat lain oleh air, angin atau berbagai organisme.

Mikro organisme dapat memecah beberapa senyawa kimia dari yang sederhana seperti polisakarida, asam amino dan lain-lain sampai yang sangat kompleks seperti residu tanaman, minyak mental dan lain-lain.

Sebagian besar pestisida dapat dipecah secara cepat dan metabolisme pestisida dipengaruhi oleh enzim mikrobiologi. Beberapa mikroorganisme dapat berkembang dan mampu memecah pestisida dengan mutasi rantai atau adaptasi enzim.

Detoksikasi pestisida oleh biota dapat disertai oleh satu atau lebih reaksi oksidasi, hidrolisa, dealkilasi, reduksi, pemecahan cincin aromatik dan lain-lain.

B. Detoksikasi oleh abiota.

Detoksikasi air limbah yang mengandung pestisida selain dilakukan oleh biota juga dilakukan oleh abiota.

Detoksikasi oleh abiota meliputi pengolahan secara fisika dan pengolahan secara kimia.

1. Pengolahan secara fisika

Pengolahan secara fisika dapat dilakukan dengan beberapa cara yaitu :

a. Proses penyaringan

Bahan yang mengandung pestisida disaring sehingga partikel yang besar dapat terpisah dari partikel yang kecil. Biasanya proses penyaringan ini dilakukan dengan cara melewatkan air limbah yang mengandung pestisida pada saringan pasir.

b. Proses pengendapan

Dilakukan dengan cara menambahkan suatu bahan yang mempunyai sifat selektif sehingga bahan yang tidak dikehendaki (berracun) dapat dipisahkan.

c. Proses pengenceran

Proses pengenceran ini dimaksudkan supaya konsentrasi bahan beracun menjadi kecil sehingga sifat racun dari zat menjadi berkurang.

d. Proses penggumpalan

Dilakukan dengan cara menambahkan suatu bahan yang dapat menggumpalkan bahan yang beracun dan selanjutnya bahan tersebut dipisahkan dari yang lain.

e. Proses penyerapan

Proses penyerapan ini ada 2 macam yaitu proses penyerapan pada seluruh bagian dari zat (absorpsi) dan proses penyerapan pada permukaan zat (adsorpsi). Proses penyerapan dilakukan dengan cara menambahkan bahan yang mampu menyerap bahan yang dikehendaki sehingga mudah dipisahkan dari yang lain. 
2. Pengolahan secara kimia

Pengolahan secara kimia meliputi :

a. Proses oksidasi

Proses oksidasi untuk menghilangkan pestisida pada air limbah biasanya dilakukan dengan menggunakan ozon, peroksida atau aerasi.

b. Pengaturan $\mathrm{pH}$

Dilakukan dengan cara menambahkan suatu asam atau basa sehingga bahan yang beracun dapat mudah dipisahkan/dihilangkan.

c. Proses reduksi

Proses reduksi dilakukan dengan menambahkan reduktor pada air limbah yang mengandung pestisida sehingga senyawa racun menjadi tidak beracun.

d. Proses hydrolisa

Dilakukan dengan cara menambahkan suatu alkali, biasanya dipergunakan alkali kuat, sehingga bahan yang beracun akan terurai menjadi bahan yang tidak beracun.

\section{PENGGUMPALAN DAN PENGENDAPAN}

Penggumpalan dan pengendapan air limbah pestisida dengan bantuan bahan koagulan dan "flocculating agent" merupakan cara yang efektif. Percobaan yang dilakukan oleh PDPI (Pesticide Development Programme India) pada pengolahan air limbah yang mengandung bahan aktif Metribuzin menunjukkan Alum (aluminium sulfat) diakui sebagai bahan yang baik untuk menggumpalkan partikel berukuran koloid. Sebagai contoh, pada tabel 1 memperlihatkan pemakaian $\mathrm{Al}_{2}$ $\left(\mathrm{SO}_{4}\right)_{3}$ dengan dosis yang berbeda untuk mengendapkan Metribuzin pada beberapa konsentrasi dalam air limbah.

Pengendapan merupakan cara yang efektif untuk mengurangi konsentrasi pestisida sampai batas kelarutan.

Dari percobaan pada air limbah yang mengandung bahan aktif metribuzin dengan proses pengendapan dengan dosis $\mathrm{Al}_{2}\left(\mathrm{SO}_{4}\right)_{3}: 200 \mathrm{ppm}$ dan $500 \mathrm{ppm}$, diperoleh hasil pengurangan konsentrasi metribuzin dari $2000 \mathrm{ppm}$ dan $3000 \mathrm{ppm}$ menjadi kira-kira 1000 ppm (dari pustaka kelarutan metrobuzin dalam air sampai 1200 ppm). Jika konsentrasi metribuzin dalam air limbah rendah, alum saja tidak efektif. 
Tabel 1. Pemakaian $\mathrm{Al}_{2}\left(\mathrm{SO}_{4}\right)_{3}$ untuk mengendapkan Metribuzin

$\begin{array}{ccc}\text { Dosis } \mathrm{Al}_{2} \begin{array}{c}\left(\mathrm{SO}_{4}\right)_{3} \\ (\mathrm{ppm})\end{array} & \begin{array}{c}\text { Konsentrasi } \\ \text { awal }(\mathrm{ppm})\end{array} & \begin{array}{r}\text { Metribuzin } \\ \text { akhir }(\mathrm{ppm})\end{array} \\ 200 & 100 & 81 \\ 500 & 100 & 90 \\ 200 & 500 & 330 \\ 500 & 500 & 315 \\ 200 & 750 & 585 \\ 500 & 750 & 585 \\ 200 & 1250 & 1050 \\ 500 & 1250 & 1125 \\ 200 & 2000 & 996 \\ 500 & 2000 & 982 \\ 200 & 3000 & 920 \\ 500 & 3000 & 1000\end{array}$

\section{PERCOBAAN PENGOLAHAN AIR LIMBAH YANG MENGANDUNG MIPC.}

A. Bahan dan peralatan

Bahan yang dipergunakan dalam percobaan ini adalah.

1. Bahan aktif MIPC (Methyl Iso Propil Karbamat) yang diperoleh dari produser bahan aktif pestisida di Surabaya.

2. Bahan penggumpal dan pengendap $\mathrm{Al}_{2}\left(\mathrm{SO}_{4}\right)_{3}$ dan Bentonit.

Peralatan yang dipergunakan adalah HPLC, neraca analitik, pengaduk dan peralatan gelas.

B. Prosedur percobaan.

Dalam percobaan ini dilakukan analisa kadar bahan aktif MIPC pada air limbah yang telah mengalami proses pengolahan. Proses pengolahan dilakukan dengan cara ke dalam air limbah ditambahkan bahan penggumpal dan atau tanpa bahan pengendap, selanjutnya campuran diaduk selama 30 menit. Sebagai air limbah, dipergunakan air suling yang diberi bahan aktif MIPC dengan konsentrasi $50 \mathrm{ppm}$.

Waktu proses pengolahan dilakukan selama $1,2,4$ \& 7 hari. Konsentrasi bahan penggumpal $\mathrm{Al}_{2}\left(\mathrm{SO}_{4}\right)_{3}$ dibuat 3 level yaitu $50,100 \& 150 \mathrm{ppm}$. Konsentrasi bahan pengendap (bentonite) yang dipergunakan 50 ppm. Analisa kadar bahan aktif dilakukan dengan menggunakan HPLC.

C. Kriteria \& pengukuran.

Dalam percobaan ini akan diteliti pengaruh waktu, konsentrasi penggumpal dan pengendap terhadap kestabilan bahan aktif MIPC.

Kriteria yang dipergunakan untuk mengukur pengaruh tersebut adalah kadar bahan aktif MIPC setelah proses pengolahan. 
D. Rencana percobaan.

Percobaan ini dilakukan menurut rancang acak lengkap secara faktorial Faktor yang diteliti pengaruhnya : Jenis bahan pengolah, konsentrasi bahan penggumpal dan waktu proses.

Faktor bahan pengolah terdiri dari 2 level yaitu tanpa dan dengan Bentonite Konsentrasi bahan penggumpal $\mathrm{Al}_{2}\left(\mathrm{SO}_{4}\right)_{3}$ terdiri atas 3 level yaitu 50 : 100 dan $150 \mathrm{ppm}$. Waktu proses terdiri dari 4 level yaitu $1 ; 2 ; 4$ dan 7 hari, sedangkan ulangan dilakukan 2 kali.

\section{HASI DAN PEMBAHASAN}

Hasil analisa kadar bahan aktif dapat dilihat pada lampiran 1 dari hasil analisa statistik diperoleh daftar sidik ragam lampiran 2.

Dari hasil analisa keragamannya, ternyata bahwa waktu proses $1,2,4$ dan 7 hari menunjukkan perbedaan sangat nyata. Hal ini jelas karena makin lama waktu yang dibutuhkan untuk proses pengolahan makin sempurna kontak antara bahan pengolahan (penggumpal \& pengendap) dengan bahan aktif pestisida tersebut. Antara pengolahan yang mengunakan bentonite sebagai bahan pengendap dan tanpa bentonite menunjukkan perbedaan yang sangat nyata. Ini dapat dimengerti sebab proses yang terjadi juga berbeda. Demikian juga dengan perlakuan yang menggunakan konsentrasi bahan penggumpal yang berbeda, memberikan perbedaan sangat nyata, karena proses pengolahan yang terjadi juga berbeda.

Interaksi antara waktu proses dan jenis bahan pengolah menunjukkan pengaruh nyata. Demikian juga interaksi antara waktu proses dan konsentrasi bahan penggumpal $\mathrm{Al}_{2}\left(\mathrm{SO}_{4}\right)_{3}$ juga menunjukkan beda nyata. Hal ini berarti bahwa waktu proses pengolahan merupakan faktor utama yang mempengaruhi jenis bahan pengolah maupun konsentrasi bahan penggumpal.

Interaksi antara jenis bahan pengolah dan konsentrasi bahan penggumpal menunjukkan pengaruh nyata. Ini berarti konsentrasi bahan penggumpal berpengaruh pada proses pengendapan yang terjadi.

Interaksi 3 faktor antara waktu proses, jenis bahan pengolah dan konsentrasi bahan penggumpal menunjukkan pengaruh nyata. Hal ini jelas sebab interaksi masing-masing antara waktu proses dengan jenis bahan pengolah, waktu proses dengan konsentrasi bahan penggumpal maupun interaksi antara jenis bahan pengolah dengan konsentrasi bahan penggumpal juga menunjukkan pengaruh nyata.

\section{KESIMPULAN}

1. Waktu proses pengolahan sangat mempengaruhi hasil dari pengolahan yaitu makin lama waktu yang diperlukan makin lama waktu kontak antara bahan aktif dengan bahan pengolah sehingga hasil dari pengolahan makin baik.

2. Jenis bahan pengolah dan konsentrasi bahan penggumpal mempengaruhi hasil pengolahan sebab proses pengolahan yang terjadi tergantung pada bahan yang dipergunakan.

Pengolahan dengan cara penggumpalan dengan disertai proses pengendapan memberikan hasil yang lebih baik. 
Lampiran 1. Tabulasi data kadar bahan aktif (ppm).

\begin{tabular}{|c|c|c|c|c|c|}
\hline \multirow[t]{2}{*}{ No. } & \multirow[t]{2}{*}{ Perlakuan } & \multicolumn{2}{|c|}{ Ulangan } & \multirow{2}{*}{ Jumlah } & \multirow[t]{2}{*}{ rata-rata } \\
\hline & & I & II & & \\
\hline 1. & $\mathrm{~A} 1, \mathrm{~B} 1, \mathrm{C} 1$ & 40.0 & 40.07 & 80.07 & 40.035 \\
\hline 2. & $\mathrm{~A} 1, \mathrm{~B} 1, \mathrm{C} 2$ & 36.10 & 36.00 & 72.1 & 36.05 \\
\hline 3. & $\mathrm{~A} 1, \mathrm{~B} 1, \mathrm{C} 3$ & 36.0 & 36.0 & 72 & 36 \\
\hline 4. & $\mathrm{~A} 2, \mathrm{~B} 1, \mathrm{C} 1$ & 28,0 & 27.95 & 55.95 & 27.975 \\
\hline 5. & $\mathrm{~A} 2, \mathrm{~B} 1, \mathrm{C} 2$ & 24.0 & 24.50 & 48.5 & 24.25 \\
\hline 6. & $\mathrm{~A} 2, \mathrm{~B} 1, \mathrm{C} 3$ & 20.0 & 20.06 & 40.06 & 20.03 \\
\hline 7. & $\mathrm{~A} 3, \mathrm{~B} 1, \mathrm{C} 1$ & 18.05 & 18.03 & 36.08 & 18.04 \\
\hline 8. & $\mathrm{~A} 3, \mathrm{~B} 1, \mathrm{C} 2$ & 16.10 & 16.0 & 32.1 & 16.05 \\
\hline 9. & $\mathrm{~A} 3, \mathrm{~B} 1, \mathrm{C} 3$ & 14.02 & 14.0 & 28.02 & 14.01 \\
\hline 10. & $\mathrm{~A} 4, \mathrm{~B} 1, \mathrm{C} 1$ & 16.0 & 15.95 & 31.95 & 15.975 \\
\hline 11. & $\mathrm{~A} 4, \mathrm{~B} 1, \mathrm{C} 2$ & 11.96 & 12.0 & 23.98 & 11.99 \\
\hline 12. & $\mathrm{~A} 4, \mathrm{~B} 1, \mathrm{C} 3$ & 10.0 & 10.04 & 20.04 & 10.02 \\
\hline 13. & $\mathrm{~A} 1, \mathrm{~B} 2, \mathrm{C} 1$ & 49.98 & 50.0 & 99.98 & 49.99 \\
\hline 14. & $\mathrm{~A} 1, \mathrm{~B} 2, \mathrm{C} 2$ & 48.34 & 48.32 & 96.66 & 48.33 \\
\hline 15. & $\mathrm{~A} 1, \mathrm{~B} 2, \mathrm{C} 3$ & 50.0 & 50.0 & 100 & 50 \\
\hline 16. & $\mathrm{~A} 2, \mathrm{~B} 2, \mathrm{C} 1$ & 49.98 & 50.99 & 99.98 & 49.99 \\
\hline 17. & $\mathrm{~A} 2, \mathrm{~B} 2, \mathrm{C} 2$ & 38.10 & 38.05 & 76.15 & 38.075 \\
\hline 18. & $\mathrm{~A} 2, \mathrm{~B} 2, \mathrm{C} 3$ & 30.04 & 30.0 & 60.04 & 30.02 \\
\hline 19. & $\mathrm{~A} 3, \mathrm{~B} 2, \mathrm{C} 1$ & 44.03 & 44.01 & 88.04 & 44.02 \\
\hline 20. & $\mathrm{~A} 3, \mathrm{~B} 2, \mathrm{C} 2$ & 34.0 & 33.96 & 67.96 & 33.98 \\
\hline 21. & A3, B2, C3 & 22.0 & 22.0 & 44 & 22 \\
\hline 22. & $\mathrm{~A} 4, \mathrm{~B} 2, \mathrm{C} 1$ & 40.01 & 40.0 & 80.01 & 40.005 \\
\hline 23. & $\mathrm{~A} 4, \mathrm{~B} 2, \mathrm{C} 2$ & 30.0 & 29.98 & 59.96 & 29.99 \\
\hline 24. & $\mathrm{~A} 4, \mathrm{~B} 2, \mathrm{C} 3$ & 14.04 & 14.02 & 28.06 & 14.03 \\
\hline
\end{tabular}

Keterangan:

$A=$ Waktu pengolahan, 1, 2, 4\& 7 hari.

A1 = waktu pengolahan satu hari.

A2 = waktu pengolahan 2 hari

A3 = waktu pengolahan 4 hari

$\mathrm{A4}=$ waktu pengolahan 7 hari

$B=$ Jenis bahan pengolah, dengan dan tanpa Bentonit.

$\mathrm{B1}=$ jenis bahan pengolah dengan bentonit.

B2 = jenis bahan pengolah tanpa bentonit.

$\mathrm{C}=$ konsentrasi bahan penggumpal A12(SO4)3).

$\mathrm{C} 1=$ konsentrasi A12 (SO4)3 $50 \mathrm{ppm}$

$\mathrm{C} 2$ = konsentrasi $\mathrm{A} 12$ (SO4)3 $100 \mathrm{ppm}$

C3 $=$ konsentrasi A12 (SO4)3 $150 \mathrm{ppm}$. 
Lampiran 2 Daftar sidik ragam kadar bahan aktif (ppm).

\begin{tabular}{lrrrrrr}
$\begin{array}{l}\text { Sumber } \\
\text { Keragaman }\end{array}$ & $\begin{array}{l}\text { Derajat } \\
\text { bebas }\end{array}$ & $\begin{array}{l}\text { Jumlah } \\
\text { Kwadrat }\end{array}$ & $\begin{array}{l}\text { kwadrat } \\
\text { tengah }\end{array}$ & \multicolumn{1}{l}{ F Hitung } & \multicolumn{2}{c}{ T tabel } \\
Perlakuan & 23 & 8.110 .719 & 352.64 & $58.773 .33 * *$ & 1.98 & 2.66 \\
A & 3 & 3.650 .715 & 1.216 .9 & $202.816 .66 * *$ & 3.01 & 4.72 \\
B & 1 & 2.700 .15 & 2.700 .15 & $450025 * *$ & 4.26 & 7.82 \\
C & 2 & 1.011 .625 & 505.81 & $84.301 .66 * *$ & 3.4 & 5.61 \\
AB & 3 & 42.069 & 14.02 & $2.336 .66 * *$ & 3.01 & 4.72 \\
BC & 2 & 249.081 & 41.51 & $6.918 .33 * *$ & 3.4 & 5.61 \\
AC & 6 & 265.934 & 132.97 & $22.161 .66 * *$ & 2.51 & 3.67 \\
ABC & 6 & 191.145 & 31.86 & $5310 * *$ & 2.51 & 3.67 \\
Sisa & 24 & 0.1473 & 0.006 & & & \\
Total & 47 & & & & &
\end{tabular}

\section{DAFTAR PUSTAKA}

1. Abdul Quddus, Pesticides in Aquatic Environments, Plenum Press, New York \& London.

2. Dutta, V.N, Effluent Treatment and waste Disposal in a Pesticide.

Formulation Plant. Presented at Workshop on Pesticide.

Formulation Technology, New Delhi, India, 9-27 March 1987.

3. Hill, I.R. 1978, Pesticide Mierobiology, Academic Press, London, New York, San Francisco.

** Sangat nyata dengan selang kepercayaan $99 \%$ 